\title{
PERBEDAAN KECEMASAN DALAM MENGHADAPI UJIAN ANTARA SISWA PROGRAM REGULER DENGAN SISWA PROGRAM AKSELERASI DI SMA SWASTA AL-AZHAR MEDAN
}

\author{
Rina Mirza \\ IAIN Sumatera Utara \\ rinamirza.psi@gmail.com
}

\begin{abstract}
The study was conducted to determine differences between test anxieties in the face of regular program students with high school students in the accelerated program Al-Azhar Medan. The sample used in this study amounted to 66 people consisting of 33 people from the accelerated program students of class XI and XII (taken entirely) and 33 men from the regular program class XII students (using random sampling techniques). Measurement tool used in this study were anxiety scale in the exam. Test different power aitem using Pearson product moment technique and test results obtained by using try out unused. The results showed that there is no difference between test anxiety in the face of regular program students and students in high school acceleration programs Private Al-Azhar Medan. It is known from the results of the test $t$-test with $\alpha=0.05$ where anxiety scores in the exam shows the results of significance $t=$ 0.143 and $p=0.887$, where $p>0.05$. Based on the average values have been obtained in this study, it can be seen that the empirical mean anxiety in students Acceleration program $e=120.79 \mu$ is 120.79 lower than the hypothetical mean is $130(<h \mu=130)$, but still middle category. Similarly in the Regular program students, concern the empirical mean $121.61 \mathrm{e}=121.61 \mu$ lower than the hypothetical mean is $130(<h=130), \mu$ but still in the moderate category. In general, it is stated that in the exam anxiety experienced by students and student programs Regular Acceleration program is lower than the average population is assumed.
\end{abstract}

Keywords: Anxiety, Regular Class, Accelerated Class

\begin{abstract}
Abstrak
Penelitian bertujuan untuk menentukan perbedaan tingkat kecemasan dalam menghadapi tes siswa SMA kelas regular dan akselerasi di Al-Azhar Medan. Sampel berjumlah 66 siswa (33 dari kelas XI dan XII) akselerasi dan 33 dari kelas XII regular dengan teknik random sampling. Alat ukur yaitu skala kecemasan dalam ujian. Uji perbedaan dengan teknik produk-momen Pearson dengan hasil tes. Hasilnya tidak ada perbedaan kecemasan tes antara siswa kelas regular dan siswa program akselerasi. Hasil uji t dengan $\alpha=0,05$ bahwa skor kecemasan dalam ujian menunjukkan hasil yang signifikan yaitu $t=-0,143$ dan $p=0,887$. Rata-rata empiris dari kecemasaan pada siswa program akselerasi e $=$ $120.79 \mu$ is 120.79 lebih rendah daripada rata-rata hipotetis yaitu $130(<h \mu=130)$, namun masih pada kategori sedang. Pada program regular, rata-rata empiris sebesar $121.61 e=121.61 \mu$ lebih rendah daripada rata-rata hipotesis yaitu $130(<h=130)$. Kecemasan ujian yang dirasakan oleh siswa regular dan akselesasi lebih rendah daripada populasi yang diasumsikan.
\end{abstract}

Kata Kunci: Kecemasan, Kelas Reguler, Kelas Akselerasi

Diterima: 29 Juli 2014

Direvisi: 29 Agustus 2014

Disetujui: 6 September 2014 


\section{PENDAHULUAN}

Salah satu cara untuk meningkatkan taraf hidup bangsa dapat dilakukan melalui pendidikan, karena dengan pendidikan dapat meningkatkan kualitas serta mengembangkan potensi sumber daya manusia. Seperti yang tertuang dalam Undang-Undang Republik Indonesia No.20 tahun 2003, bahwa tujuan Pendidikan Nasional adalah untuk mengembangkan potensi peserta didik agar menjadi manusia yang beriman dan bertakwa kepada Tuhan Yang Maha Esa, berakhlak mulia, sehat, berilmu, cakap, kreatif, mandiri dan menjadi warga negara yang demokratis serta bertanggung jawab (Depdiknas, 2003).

Dalam menyelenggarakan pendidikan, pada awalnya pemerintah telah menetapkan suatu program pendidikan yang bersifat reguler yaitu penyelenggaraan pendidikan yang bersifat massal yakni berorientasi pada kuantitas/ jumlah untuk dapat melayani sebanyak-banyaknya siswa usia sekolah (Latifah, dalam Hawadi, 2004). Namun pada kenyataannnya program reguler ini tidak dapat memenuhi semua kebutuhan siswa dan mempunyai kelemahan yakni tidak terakomodasikannya kebutuhan individual siswa. Siswa yang relatif lebih cepat nalarnya daripada yang lainnya tidak terlayani secara baik sehingga potensi yang dimilikinya tidak dapat berkembang secara optimal.

Berdasarkan pengalaman, siswa yang memiliki kemampuan intektual jauh di atas rata-rata cenderung lebih cepat menguasai materi pelajaran yang disampaikan oleh gurunya. Akibatnya, siswa ini akan mengganggu siswa lain yang lebih lamban dari dirinya. Siswa yang berkemampuan jauh di atas rata-rata ini, biasanya lebih sering terkesan santai dan tampak kurang memperhatikan pelajaran. Hal yang lebih buruk lagi, siswa tersebut cenderung mengganggu temannya, sehingga kegiatan belajar mengajar dalam kelas menjadi kurang lancar (Latifah, dalam Hawadi, 2004). Untuk melayani siswa tersebut, diperlukan program khusus yang lebih cepat atau lebih luas dari program reguler.

Berkenaan dengan hal tersebut di atas, pemerintah telah mengeluarkan Undang-Undang Republik Indonesia Nomor 20 Tahun 2003 tentang Sistem Pendidikan Nasional pasal 5 ayat (4) bahwa warga negara yang memiliki potensi kecerdasan dan bakat istimewa berhak memperoleh pendidikan khusus (Depdiknas, 2003). Selanjutnya, khusus untuk pendidikan menengah, diatur dalam PP Nomor 29 tahun 1990 yang ditindaklanjuti dengan keputusan Mendikbud Nomor 0489/U /1992 untuk SMA. Dalam keputusan Mendikbud tersebut, pasal 16 ayat (1) menyebutkan bahwa siswa yang memiliki bakat istimewa dan kecerdasan luar biasa dapat menyelesaikan program belajar lebih awal dari waktu yang telah ditentukan, dengan ketentuan telah mengikuti pendidikan SMA sekurang-kurangnya dua tahun (Nasichin, dalam Hawadi, 2004). 
Landasan hukum akan pentingnya pemberian perhatian khusus kepada peserta didik yang memiliki kemampuan dan kecerdasan luar biasa (berbakat) memperkuat asumsi bahwa kelompok peserta didik memiliki kebutuhan yang berbeda dari peserta didik yang berkemampuan dan memiliki kecerdasan normal. Dalam usahanya untuk menangani anak-anak berbakat, pada tahun 1998/ 1999 pemerintah mengeluarkan kebijakan untuk membuat program percepatan atau lebih dikenal dengan istilah akselerasi. Salah satu sekolah di Medan yang telah menyelenggarakan program reguler dan program akselerasi di sekolahnya adalah SMA Swasta Al-Azhar Medan yang terletak di Jln. Pintu Air IV no. 214 Kwala Bekala Padang Bulan-Medan.

Program akselerasi merupakan pemberian layanan pendidikan sesuai potensi siswa yang berbakat, dengan memberi kesempatan kepada siswa untuk menyelesaikan program pendidikan dalam jangka waktu yang lebih cepat dibandingkan dengan teman-temannya, dan program akselerasi ini diselenggarakan pada jenjang SD sampai dengan SMA (Christina, dalam Buletin, 2004). Waktu yang digunakan untuk menyelesaikan program belajar dapat dipercepat sesuai dengan potensi siswa dan waktu yang digunakan untuk menyelesaikan program belajar bagi siswa yang memiliki potensi kecerdasan dan bakat istimewa lebih cepat dibandingkan siswa reguler. Pada satuan pendidikan SD dari 6 tahun dapat dipercepat menjadi 5 tahun, SMP dan SMA masing-masing 3 tahun dapat dipercepat menjadi 2 tahun (Gerbang, 2004).

Pengertian anak berbakat dalam program percepatan belajar atau akselerasi yang dikembangkan oleh pemerintah dapat dibatasi pada dua hal sebagai berikut: (1) mereka mempunyai taraf kecerdasan atau IQ diatas 140. (2) mereka yang oleh psikolog dan/ atau guru diidentifikasikan sebagai peserta didik yang telah mencapai prestasi yang memuaskan, dan memiliki kemampuan intelektual umum yang berfungsi pada taraf cerdas, dan keterikatan terhadap tugas yang tergolong baik serta kreativitas yang memadai (Depdiknas, 2001). Menurut Hawadi (1998), bagi anak berbakat tingkat SMA, taraf kecerdasannya atau Intellectual Quotient 120 keatas (skala TIKI), Creative Quotient 110 (skala TKV-URH) dan Task Commitment 126 keatas (skala YA/ FS Revisi). Namun dalam pelaksanaannya, Soemantri (2005) menyatakan bahwa keberbakatan tidak hanya ditinjau dari segi kecerdasan tetapi dilihat dari segi prestasi, kreatifitas dan karakteristik pribadi/ sosial lainnya, dilihat dari kemampuan yang bersifat potensial maupun aktual/ prestasi.

Untuk SMA Swasta Al-Azhar Medan sendiri, mereka sudah menerapkan kreteria-kreteria tertentu untuk meluluskan siswanya agar dapat memasuki kelas program akselerasi yaitu sebelum masuk siswa harus dites terlebih dahulu dan harus lulus tes IQ minimal 125 skala weisler, tes emosional, kreativitas, komitmen harus baik dan penilaian IP. Selain itu, 
apabila telah lulus siswa program akselerasi selalu dipantau untuk mengembangkan prestasinya (hasil wawancara, 2006).

Dalam model kurikulum, akselerasi berarti mempercepat bahan ajar dari yang seharusnya dikuasai oleh siswa saat itu. Dalam hal ini, akselerasi dapat dilakukan dalam kelas reguler, ataupun kelas khusus dan bentuk akselerasi yang diambil bisa telescoping, yaitu siswa menggunakan waktu yang kurang dari biasanya dengan menyelesaikan studinya. Selain itu, siswa dapat menyelesaikan dua tahun atau lebih kegiatan belajarnya menjadi satu tahun atau dengan cara self-paced studies, yaitu siswa diperkenalkan pada materi pelajaran yang memungkinkannya untuk mengatur sendiri kemajuan-kemajuan yang bisa diperolehnya sesuai dengan tempo yang dimilikinya atau siswa mengatur kecepatan belajarnya sendiri (Hawadi, 2004).

Dalam program akselerasi ini, siswa diupayakan untuk dapat mengikuti dan menyelesaikan program pendidikannya lebih cepat dari program reguler. Dengan masuknya seseorang sebagai siswa akselerasi, sebutan maupun harapan yang diberikan oleh masyarakat semakin tinggi kepada mereka. Menurut Fawzia (dalam Hawadi, 2004), siswa akselerasi dinominasikan oleh guru, teman-teman dan orang tua, sebagai anak yang paling hebat dan paling pandai dibandingkan siswa reguler lainnya. Sebutan tersebut membuat siswa akselerasi mengalami tekanan. Hal ini didukung oleh pendapat Moeslow (dalam Hawadi, 2004) yang berpendapat bahwa siswa akselerasi termasuk anak yang berbakat dan merupakan anak-anak yang banyak mengalami tekanan dari lingkungannya.

Tekanan dari lingkungan tersebut dikarenakan adanya harapan yang tinggi dari orang tua agar menjadi anak yang sukses atau desakan masyarakat agar menjadi individu yang bermanfaat dimasyarakat, serta anggapan guru dan teman-teman agar dapat berhasil dalam menentukan pilihan karier dikemudian hari (Alim, dalam Hawadi, 2004). Tekanan yang mereka rasakan tersebut dapat mengakibatkan terjadinya kecemasan. Chaplin (2001), menjelaskan bahwa kecemasan merupakan perasaan campuran yang berisikan ketakutan dan keprihatinan mengenai masa-masa mendatang tanpa sebab khusus untuk ketakutan tersebut. Jadi kecemasan itu sendiri merupakan kekuatan yang besar dalam menggerakkan tingkah laku, baik tingkah laku yang normal maupun tingkah laku yang menyimpang.

Menurut Albin (2003), kecemasan yang ada dapat memberi pengaruh yang positif bila individu menjadi lebih bergairah. Sebaliknya dapat memberikan pengaruh negatif jika kecemasan sudah berlebihan sehingga menyebabkan individu tersebut putus asa. Jadi kecemasan ini tidak menjadi suatu masalah jika individu tersebut mampu mengelola rasa cemas sehingga tidak mengganggu keseimbangan dirinya. Umpamanya, perasaan cemas yang tidak begitu dirasakan tentang bahaya tidak dapat menjawab pertanyaan dalam ujian, melindungi kita dari kegagalan, karena memaksa 
kita untuk belajar. Tetapi perasaan cemas yang hebat dapat menghalangi kita untuk pergi ke sekolah. Dengan demikian, kita tidak hanya akan gagal dalam ujian, tetapi juga akan gagal dalam kehidupannya.

Kecemasan tersebut, terutama sekali akan terjadi saat siswa menghadapi ujian sebab ujian merupakan suatu tolok ukur bagi keberhasilan siswa dalam menempuh proses pendidikannya ke jenjang selanjutnya. Seperti yang dinyatakan Shadily (2002) bahwa ujian merupakan suatu pemeriksaan mengenai pengetahuan, keahlian atau kecerdasan seseorang (siswa) untuk diperkenankan atau tidak dalam mengikuti pendidikan tingkat tertentu. Hal ini menunjukkan bahwa optimalnya hasil belajar siswa bergantung pada bagaimana proses belajar serta kesungguhan mereka dalam menjalani ujian, sehingga siswa diperkenankan untuk mengikuti pendidikan kejenjang selanjutnya.

Berdasarkan wawancara yang dilakukan kepada salah seorang Guru di SMA Swasta Al-Azhar Medan, diketahui bahwa siswa akselerasi di SMA Swasta Al-Azhar, khususnya lebih siap menghadapi ujian sebab mereka sudah sering mengalami simulasi di akhir pelajaran. Sementara bagi siswa reguler sendiri, mereka jarang mengalami simulasi sehingga ketika ujian tiba tidak jarang dari mereka yang kurang siap dan sebagian lainnya mengambil les private tambahan (hasil wawancara, 2006). Dalam kesempatan yang sama, peneliti mencoba mewawancarai salah seorang siswa program akselerasi, ia menyatakan bahwa baginya rasa cemas pastilah ada, karena guru-guru selalu memacu mereka untuk mencapai nilai yang baik dari satuan pelajaran yang diinginkan oleh pihak sekolah (hasil wawancara, 2006). Hal senada juga dikatakan oleh salah seorang siswa program reguler, bahwa perasaan cemas dan takut gagal pasti ada (hasil wawancara, 2006).

\section{METODE}

Metode pendekatan yang digunakan dalam penelitian ini adalah pendekatan kuantitatif. Sampel yang digunakan berjumlah 66 orang yang terdiri dari 33 orang dari siswa program akselerasi kelas XI^XII (diambil seluruhnya) dan 33 orang dari siswa program reguler kelas XII (mempergunakan teknik random sampling). Alat ukur yang digunakan dalam penelitian ini adalah skala kecemasan dalam menghadapi ujian. Uji daya beda aitem menggunakan teknik pearson product moment dan diperoleh hasil ujicoba dengan menggunakan try out terpakai.

Teknik yang digunakan untuk mengukur reliabilitas skala kecemasan dalam menghadapi ujian adalah koefisien alpha Cronbach ( $\alpha$ ), dan diperoleh nilai alpha crobachnya 0,955 . Hal ini menyatakan bahwa skala kecemasan dalam menghadapi ujian adalah reliabel dengan menggunakan program SPSS for Windows Release 12.0. 


\section{HASIL}

Sesuai dengan tujuan dalam penelitian ini, yaitu untuk mengetahui perbedaan kecemasan dalam menghadapi ujian antara siswa program reguler dengan siswa program akselerasi. Untuk itu, hipotesis pada penelitian ini adalah IIterdapat perbedaan kecemasan dalam menghadapi ujian antara siswa program reguler dengan siswa program akselerasi di SMA Swasta Al-Azhar Medanll. Diasumsikan bahwa siswa program akselerasi mengalami kecemasan yang lebih tinggi dibandingkan siswa program reguler dalam menghadapi ujian.

Berdasarkan hasil pengujian t-test dengan $\alpha=0,05$ diketahui skor kecemasan dalam menghadapi ujian menunjukkan hasil signifikansi $\mathrm{t}=$ 0,143 dengan $p=0,887$, dimana $p>0,05$. Hal ini menunjukkan bahwa Ha ditolak dan Ho diterima, berarti tidak terdapat perbedaan kecemasan dalam menghadapi ujian antara siswa program reguler dan siswa program akselerasi. Untuk lebih jelasnya, dapat dilihat pada tabel berikut,

Tabel 1

Rangkuman Hasil Penelitian

\begin{tabular}{llllll}
\hline & Kelas & N & Mean & Std. Deviation & $\begin{array}{c}\text { Std. Error } \\
\text { Mean }\end{array}$ \\
\hline Kelas & Aksel & 33 & 120.79 & 23.39 & 4.07 \\
& Reguler & 33 & 121.61 & 23.05 & 4.01 \\
\hline
\end{tabular}

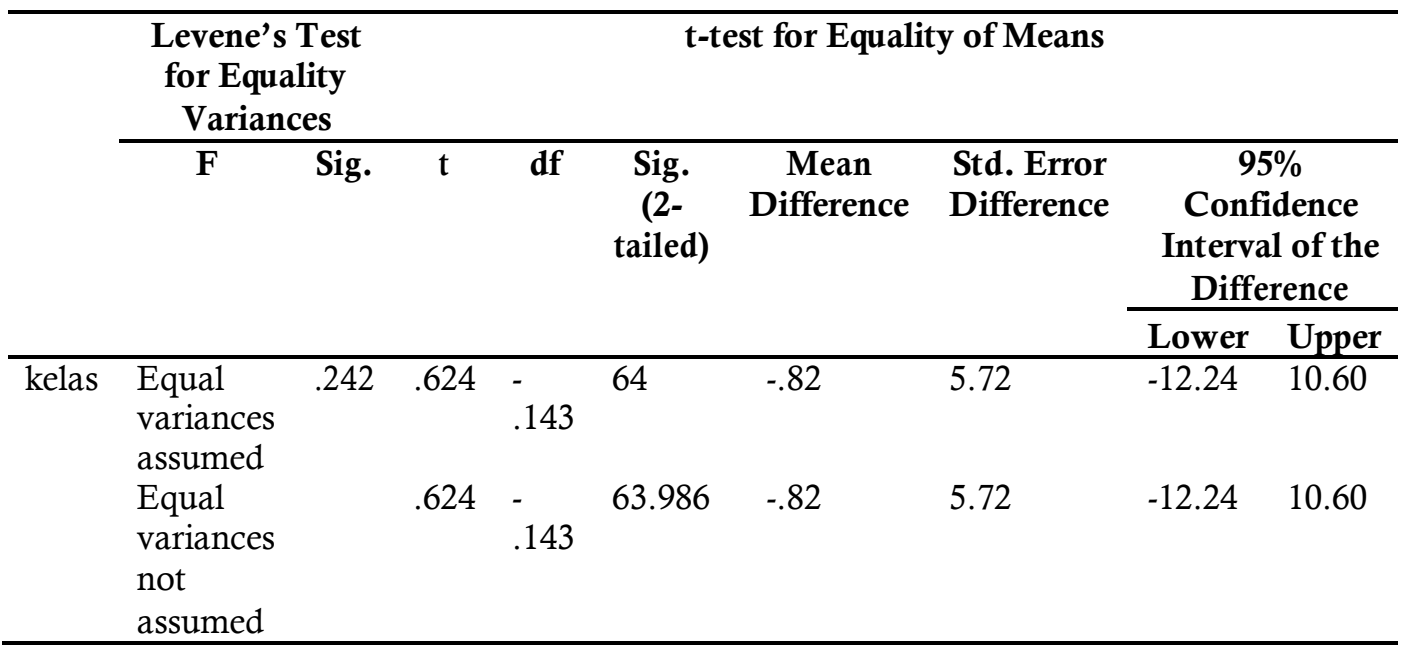

\section{Mean Hipotetik dan Mean Empirik}

Untuk mengetahui bagaimana kondisi kecemasan dalam menghadapi ujian pada subjek penelitian ini adalah dengan cara membandingkan antara nilai rata-rata hipotetik dengan nilai rata-rata empiriknya.Skala kecemasan terdiri 
dari 52 aitem yang masing-masing aitemnya diberi skor yang berkisar mulai dari 1, 2, 3, 4 (diformat dengan menggunakan skala Likert), dengan demikian skor hipotetik minimum yang mungkin dicapai adalah $52 \times 1=52$ dan skor hipotetik maksimum adalah $52 \times 4=208$. Oleh karena itu rentang skor skala kecemasan adalah $208-52=156$, dan dibagi dalam 6 satuan standar deviasi maka diperoleh standar deviasi hipotetiknya adalah 156/ 6 $=26$. Angka 26 adalah estimasi standar deviasi populasi yang akan kita gunakan untuk kategorisasi subjek.

Sementara itu, Mean hipotetik/ teoritis dari skala kecemasan adalah $\{(52+208): 2\}=130$. Berdasarkan perhitungan mean empiris dan hipotetik dari skala kecemasan dapat kita lihat pada tabel berikut,

\section{Tabel 2}

Perbandingan Skor Hipotetik dan Skor Empirik Skala Kecemasan dalam Menghadapi Ujian

\begin{tabular}{llllllllc}
\hline \multirow{2}{*}{ Kelas } & \multicolumn{4}{c}{ Hipotetik } & \multicolumn{4}{c}{ Empirik } \\
\cline { 2 - 9 } & Min & Maks & Mean & SD & Min & Maks & Mean & SD \\
\hline Akselerasi & 52 & 208 & 130 & 26 & 58 & 183 & 120.79 & 23.393 \\
Reguler & 52 & 208 & 130 & 26 & 66 & 165 & 121.61 & 23.051 \\
\hline
\end{tabular}

Dari tabel di atas dapat dilihat bahwa mean empiris skala kecemasan pada kelas Akselerasi yaitu 120,79 lebih rendah dari mean hipotetik yaitu $130(\mu \mathrm{e}=120,79<\mu \mathrm{h}=13)$. Hal ini berarti secara umum kecemasan dalam menghadapi ujian yang dialami oleh siswa kelas Akselerasi adalah lebih rendah dari rata-rata populasi yang diasumsikan. Mean empiris skala kecemasan pada kelas Reguler yaitu 121,61 lebih rendah dari mean hipotetik yaitu $130(\mu \mathrm{e}=121,61<\mu \mathrm{h}=130)$. Hal ini berarti secara umum kecemasan dalam menghadapi ujian yang dialami oleh siswa kelas Reguler adalah lebih rendah dari rata-rata populasi yang diasumsikan.

\section{Hasil Tambahan}

Berdasarkan hasil deskripsi data penelitian dapat dilakukan pengelompokan yang mengacu pada kriteria kategorisasi. Azwar (2000) menyatakan bahwa kategorisasi didasarkan pada asumsi bahwa skor subjek penelitian terdistribusi secara normal. Berdasarkan perhitungan Mean dan standar deviasi hipotetik di atas, skor skala kecemasan pada siswa program akselerasi dan siswa program reguler dapat dikategorisasikan dalam lima jenjang kategorisasi yaitu kecemasan yang sangat tinggi, tinggi, sedang, rendah dan sangat rendah, dengan norma kategorisasi sebagai berikut; 


$$
\begin{aligned}
& X \leq \mu-1.5 \sigma \\
& \mu-1.5 \sigma X \leq \mu-0.5 \sigma \\
& \mu-0.5 \quad \sigma<X \quad \leq \mu+0.5 \sigma \\
& \mu+0.5 \sigma<X \leq \mu+1.5 \sigma \\
& \mu+1.5 \sigma<X
\end{aligned}
$$

Sangat rendah

Rendah

Sedang

Tinggi

Sangat Tinggi

\section{Tabel 3}

Kategorisasi Skor Skala Kecemasan dalam Menghadapi Ujian Siswa Program Reguler

\begin{tabular}{llccc}
\hline & \multicolumn{1}{c}{ Nilai } & Kategorisasi & Jumlah & Frekuensi \\
\hline $\mathrm{X} \leq \mu-1.5 \sigma$ & $\mathrm{X} \leq 104$ & Sangat Rendah & 8 & $24.24 \%$ \\
$\mu-1.5 \sigma<\mathrm{X} \leq \mu-0.5 \sigma$ & $104<\mathrm{X} \leq 117$ & Rendah & 4 & $12.12 \%$ \\
$\mu-0.5 \sigma<\mathrm{X} \leq \mu+0.5 \sigma$ & $117<\mathrm{X} \leq 143$ & Sedang & 15 & $45.45 \%$ \\
$\mu+0.5 \sigma<\mathrm{X} \leq \mu+1.5 \sigma$ & $143<\mathrm{X} \leq 156$ & Tinggi & 4 & $12.12 \%$ \\
$\mu+1.5 \sigma<\mathrm{X}$ & $156<\mathrm{X}$ & Sangat Tinggi & 2 & $6.06 \%$ \\
\hline
\end{tabular}

Dari tabel di atas dapat diketahui bahwa, ada 15 siswa program reguler $(45,45 \%)$ yang mengalami kecemasan pada taraf sedang, delapan siswa $(24,24 \%)$ yang mengalami kecemasan pada taraf sangat rendah, empat siswa $(12,125)$ yang mengalami kecemasan pada taraf rendah dan tinggi, serta dua siswa $(6,06 \%)$ yang mengalami kecemasan pada taraf sangat tinggi.

Tabel 4

Kategorisasi Skor Skala Kecemasan Menghadapi Ujian Siswa Program Akselerasi

\begin{tabular}{llccc}
\hline & \multicolumn{1}{c}{ Nilai } & Kategorisasi & Jumlah & Frekuensi \\
\hline $\mathrm{X} \leq \mu-1.5 \sigma$ & $\mathrm{X} \leq 104$ & Sangat Rendah & 6 & $18.18 \%$ \\
$\mu-1.5 \sigma<\mathrm{X} \leq \mu-0.5 \sigma$ & $104<\mathrm{X} \leq 117$ & Rendah & 10 & $30.30 \%$ \\
$\mu-0.5 \sigma<\mathrm{X} \leq \mu+0.5 \sigma$ & $117<\mathrm{X} \leq 143$ & Sedang & 14 & $42.42 \%$ \\
$\mu+0.5 \sigma<\mathrm{X} \leq \mu+1.5 \sigma$ & $143<\mathrm{X} \leq 156$ & Tinggi & 1 & $3.03 \%$ \\
$\mu+1.5 \sigma<\mathrm{X}$ & $156<\mathrm{X}$ & Sangat Tinggi & 2 & $6.06 \%$ \\
\hline
\end{tabular}

Dari tabel di atas diketahui bahwa 14 siswa program akselerasi $(42,42 \%)$ yang mengalami kecemasan pada taraf sedang, 10 siswa $(30,30 \%)$ yang mengalami kecemasan pada taraf rendah, enam siswa $(18,18 \%)$ yang mengalami kecemasan pada taraf rendah, dua siswa $(6,06 \%)$ yang mengalami kecemasan pada taraf sangat tinggi dan satu siswa $(3,03 \%)$ yang mengalami kecemasan pada taraf tinggi. 


\section{DISKUSI}

Berdasarkan hasil pengujian t-test dengan $\alpha=0,05$ diketahui skor kecemasan menunjukkan hasil signifikansi $\mathrm{t}=-0,143$ dengan $\mathrm{p}=0,887$, dimana $\mathrm{p}>0,05$. Dari hasil analisis tersebut, maka dapat dinyatakan bahwa Ha Ditolak, berarti tidak ada perbedaan kecemasan dalam menghadapi ujian antara siswa program reguler dan siswa program akselerasi di SMA Swasta Al-Azhar Medan. Hal ini tidak sejalan dengan pendapat Fawzia (dalam Hawadi, 2004) bahwa tuntutan, harapan dan tekanan yang dialami oleh siswa akselerasi membuat mereka cemas dalam menghadapi ujian.

Tekanan dari lingkungan tersebut dikarenakan adanya harapan yang tinggi dari orang tua agar menjadi anak yang sukses atau desakan masyarakat agar menjadi individu yang bermanfaat di masyarakat, serta anggapan guru dan teman-teman agar dapat berhasil dalam menentukan pilihan karier di kemudian hari. (Alim, dalam Hawadi, 2004).

Tidak terbuktinya hipotesa dalam penelitian ini, kemungkinan dikarenakan oleh beberapa hal, yaitu:

1. Dalam penelitian ini, kecemasan yang diukur adalah kecemasan dalam menghadapi ujian pertengahan semester. Ujian pertengahan semester bukan merupakan penentu, sehingga tidak begitu membuat cemas. Berdasarkan hasil wawancara yang dilakukan secara terpisah terhadap salah seorang siswa program akselerasi dan reguler bahwa mereka menyatakan ujian Mid (pertengahan semester) tidak membuat mereka cemas, dan tidak terlalu menakutkan, kecuali ujian akhir nanti/ UAN yang menentukan tamat tidaknya mereka dari sekolah dan mereka menganggap bahwa ujian sebagai suatu hal yang sudah selayaknya dilakukan, bukanlah sebagai suatu hal yang dirasakan sebagai paksaan dan dianggap sebagai situasi yang mengancam (hasil wawancara, 2007). Pendapat tersebut, dapat dianggap suatu hal yang wajar jika dikaitkan dengan pendapat Sudjana (2005) menyatakan bahwa ujian merupakan hasil belajar siswa yang merupakan akibat dari suatu proses belajar siswa selama menjalani pendidikannya. Senada dengan hal tersebut, Mahmud (1998) menyatakan bahwa ujian merupakan suatu penilaian yang dilakukan sebagai hasil dari suatu proses belajar mengajar.

2. Baik siswa program akselerasi maupun siswa program reguler, keduaduanya dituntut orang tua, guru dan masyarakat untuk dapat meraih sukses dan berprestasi. Tuntutan dari lingkungan tersebut dikarenakan adanya harapan yang tinggi dari orang tua agar menjadi anak yang sukses atau desakan masyarakat agar menjadi individu yang bermanfaat di masyarakat, serta anggapan guru dan teman-teman agar dapat berhasil dalam menentukan pilihan karier di kemudian hari. Seperti yang diungkapkan oleh Alim (dalam Hawadi 2004) bahwa sebutan maupun harapan yang diberikan oleh masyarakat kepada siswa akselerasi, juga dirasakan siswa program reguler. Hal tersebut diperkuat dengan 
pendapat Grainger (1999) bahwa setiap individu akan mengalami tuntutan yang berhubungan dengan dirinya sendiri baik dirumah, ditempat kerja maupun di sekolah.

3. Terdapat faktor-faktor lain yang turut mempengaruhi kecemasan dalam menghadapi ujian, tetapi tidak dikontrol dalam penelitian ini, seperti tipe kepribadian, sikap, tingkat sosial. Hal ini sesuai dengan pendapat Grainger (1999) yang menyatakan bahwa ciri kepribadian, sikap, tingkat sosial keluarga dapat mempengaruhi tingkat kecemasan seorang individu.

Berdasarkan nilai rata-rata yang telah diperoleh dalam penelitian ini, maka dapat diketahui bahwa mean empiris kecemasan pada siswa program Akselerasi yaitu 120.79 lebih rendah dari mean hipotetiknya yaitu 130 ( $\mu \mathrm{e}=$ $120,79<\mu \mathrm{h}=130$ ), namun masih berada pada kategori sedang. Demikian juga pada siswa program Reguler, mean empiris kecemasannya yaitu 121.61 lebih rendah dari mean hipotetiknya yaitu $130(\mu \mathrm{e}=121.61<\mu \mathrm{h}=130)$, namun masih dalam kategori sedang. Secara umum, dinyatakan bahwa kecemasan dalam menghadapi ujian yang dialami oleh siswa program Reguler dan siswa program Akselerasi adalah sedang.

Dari persentase hasil tambahan dalam penelitian, dapat diketahui bahwa pada siswa program reguler, ada 15 siswa $(45,45 \%)$ yang mengalami kecemasan pada taraf sedang, delapan siswa $(24,24 \%)$ yang mengalami kecemasan pada taraf sangat rendah, empat siswa $(12,125)$ yang mengalami kecemasan pada taraf rendah dan tinggi, serta dua siswa $(6,06 \%)$ yang mengalami kecemasan pada taraf sangat tinggi. Sementara itu, pada siswa program akselerasi ada 14 siswa $(42,42 \%)$ yang mengalami kecemasan pada taraf sedang, 10 siswa $(30,30 \%)$ yang mengalami kecemasan pada taraf rendah, enam siswa $(18,18 \%)$ yang mengalami kecemasan pada taraf rendah, dua siswa $(6,06 \%)$ yang mengalami kecemasan pada taraf sangat tinggi dan satu siswa $(3,03 \%)$ yang mengalami kecemasan pada taraf tinggi.

Menurut Atkinson (1999), kecemasan merupakan emosi dan emosi juga dapat bermanfaat/ bernilai positif yaitu membuat prilaku individu menjadi termotivasi untuk melakukan aktivitas tertentu, namun dapat juga menyebabkan suatu hal yang negatif, yang mengakibatkan stress sehingga menghambat/ mengganggu usaha seseorang untuk mencapai tujuannya.

Berdasarkan hasil analisis data yang telah diperoleh dalam penelitian ini, maka dapat ditarik kesimpulan sebagai berikut:

1. Tidak terdapat perbedaan kecemasan dalam menghadapi ujian antara siswa program reguler dan siswa program akselerasi di SMA Swasta AlAzhar Medan. Hal ini ditunjukkan dengan hasil pengujian $t$-test dengan $\alpha$ cronbach $=0,05$, diketahui skor kecemasan menunjukkan hasil signifikansi $t=-0,143$ dengan $p=0,887$, dimana nilai $p>0,05$.

2. Kecemasan yang dialami oleh siswa program reguler dan siswa program akselerasi lebih rendah daripada rata-rata populasi yang diasumsikan. Hal ini ditunjukkan dari mean empiris kecemasan pada siswa reguler 
yaitu 121,61 lebih rendah dari mean hipotetik yaitu $130(\mu \mathrm{e}=121.61$ $<\mu \mathrm{h}=130$ ). Sedangkan pada siswa program akselerasi mean empiris yaitu 120,79 lebih rendah dari mean hipotetik yaitu $130(\mu \mathrm{e}=120.79$ $<\mu \mathrm{h}=130$ ).

3. Bagi siswa program Reguler, ada 15 siswa $(45,45 \%)$ yang mengalami kecemasan pada taraf sedang, delapan siswa $(24,24 \%)$ yang mengalami kecemasan pada taraf sangat rendah, empat siswa $(12,125)$ yang mengalami kecemasan pada taraf rendah dan empat siswa $(12,125)$ yang mengalami kecemasan pada taraf tinggi, serta dua siswa $(6,06 \%)$ yang mengalami kecemasan pada taraf sangat tinggi. Sedangkan pada siswa program akselerasi ada 14 siswa $(42,42 \%)$ yang mengalami kecemasan pada taraf sedang, 10 siswa $(30,30 \%)$ yang mengalami kecemasan pada taraf rendah, enam siswa $(18,18 \%)$ yang mengalami kecemasan pada taraf rendah, dua siswa $(6,06 \%)$ yang mengalami kecemasan pada taraf sangat tinggi dan satu siswa $(3,03 \%)$ yang mengalami kecemasan pada taraf tinggi.

Sejalan dengan kesimpulan yang telah dibuat, maka berikut ini dapat diberikan beberapa saran, antara lain:

1. Sebaiknya pihak sekolah (guru) dan orang tua dapat membantu mengurangi kecemasan siswa dalam menghadapi ujian, terutama bagi siswa yang kecemasannya sangat tinggi. Hal ini dilakukan dengan memberi nasehat pada siswa agar lebih memfokuskan pada pelajaran, serta berupaya untuk memperoleh prestasi terbaik sesuai dengan kemampuan. Disamping itu, tidak terlalu mengkhawatirkan pada hal-hal yang dianggap dapat mempengaruhi kecemasannya dalam menghadapi ujian serta menyerap lebih banyak energi psikis sehingga mereka tidak dapat menggunakan pemikiran mereka secara optimal (memperoleh prestasi secara maksimal). Untuk siswa yang mengalami kecemasan dalam kategori sangat rendah, dikhawatirkan mereka terlalu sepele dengan ujian yang akan mereka hadapi dan hal ini juga berbahaya bagi siswa tersebut, maka pihak sekolah (guru) perlu mewaspadainya. Sedangkan siswa yang berada pada kategori sedang, tetap diwaspadai karena ada kemungkinan menjadi tinggi. Untuk itu, diharapkan bahwa kecemasan yang mereka rasakan dapat menjadi pemacu dalam berprestasi.

2. Untuk siswa, jadikanlah kecemasan yang dirarasakan sebagai pemacu dalam berprestasi dan cobalah lebih terbuka kepada guru ataupun orang tua, agar mereka dapat membantu dalam mencari jalan keluar atas kecemasan yang dirasakan ketika menghadapi ujian.

3. Untuk peneliti selanjutnya yang ingin membuat penelitian yang sejenis, maka disarankan agar:

a. Mengontrol faktor-faktor lain yang diperkirakan mempengaruhi kecemasan siswa dalam menghadapi ujian tetapi belum dikontrol dalam penelitian ini, seperti: tipe kepribadian, sikap, tingkat sosial. 
b. Membandingkan kecemasan siswa pada saat ujian pertengahan semester dengan ujian akhir semester bahkan dengan ujian penentu kelulusan seperti UAN (Ujian Akhir Nasional).

\section{DAFTAR PUSTAKA}

Albin, Rochelle, Semmel. (2003). Emosi-Bagaimana Mengenal, Menerima dan Mengarahkannya. Yogyakarta: Kanisius.

Atkinson, Rita L. (1999). Pengantar Psikologi-jilid II. Jakarta: Erlangga.

Azwar, S. (2000). Penyusunan Skala Psikologi. Yogyakarta: Pustaka Pelajar.

Buletin Pusat Perbukuan dengan Buku Jelajahi Dunia-vol 10. (2004). Program Akselerasi-Bagaimana Pelaksanaannya di Lapangan?. Jakarta: Departemen Pendidikan Nasional.

Chaplin, J.P. (2001). Kamus Lengkap Psikologi. Jakarta: PT.Raja Grafindo Persada.

Departemen Pendidikan Nasional. (2001). Pedoman Penyelenggaraan Program Percepatan Belajar (SD, SMP, dan SMA). Jakarta: Direktorat PLB Ditjen Dikdasmen.

Departemen Pendidikan Nasional. (2003). Pedoman Penyelenggaraan Program Percepatan Belajar SD, SMP, dan SMA-Suatu Model Pelayanan Pendidikan Bagi Peserta Didik Yang Memiliki Potensi Kecerdasan dan Bakat Istimewa. Jakarta: Direktorat Jendral Pendidikan Dasar dan Menengah.

Departemen Pendidikan Nasional. (2003). Undang-Undang Republik Indonesia Nomor 20 tahun 2003 Tentang Sistem Pendidikan Nasional. Jakarta: Departemen Pendidikan Nasional Republik Indonesia.

Gerbang Majalah Pendidikan-edisi 4 thn IV, terbit Oktober 2004. (2004). Pedoman Penyelenggaraan Program Percepatan Belajar SD, SMP dan SMA (Satu Model Pelayanan Pendidikan bagi Peserta Didik yang Memiliki Potensi Kecerdasan dan Bakat Istimewa). Yogyakarta: PT.Cahaya Timur Offset.

Gerbang Majalah Pendidikan-edisi 6 thn IV, terbit Desember 2004. (2004).

Membangun Bangsa Berkualitas Melalui Akselerasi

Pendidikan.Yogyakarta: PT.Cahaya Timur Offset.

Grainger, Caron. (1999). Mengatasi Stress Bagi Para Dokter. Jakarta: Hipokrates. 